\title{
The Impact of Service Quality, Technology Acceptance and Religiosity on The Selection of Islamic Bank and FinTech - Investigating The Stagnation of Indonesian Islamic Banking
}

\author{
Hidayat Wira Kusuma ${ }^{1}$, Dedi Wibowo ${ }^{2}$ \\ \{mashidayat.wk@gmail.com¹, bowo15101971@gmail.com² \\ University of Indonesia ${ }^{1}$, University Teknikal Malaysia Melaka ${ }^{2}$, Universitas Dirgantara Marsekal \\ Suryadarma ${ }^{2}$, University of Indonesia ${ }^{2}$
}

\begin{abstract}
Regardless Indonesia has the largest number of Muslim populations in the world, the market share of Indonesian Islamic banking ironically remains small. Furthermore, the present emergence of fintech is feared to threaten the traditional industry players, as well as Islamic banks. Employing the SERVQUAL and UTAUT2 model, this study attempts to investigate the influence of service quality and technology acceptance on the selection of Islamic banks and fintech, in respect of religiosity entrenched in Muslim society. This study is one of limited researches focusing on the stagnation of Indonesian Islamic banking market share. The results emphasize that Islamic banking stakeholders are suggested to arouse public awareness regarding sharia compliance in conducting financial transactions. One's belief does not significantly encourage customers to embrace Islamic banking. Meanwhile, digitalization has changed customers' paradigm to the financial service model. Therefore, Islamic banking is required to advance its technology-based products in order to overcome the challenge.
\end{abstract}

Keywords: Islamic Bank, Fintech, SERVQUAL, UTAUT2, Religiosity.

\section{Introduction}

Sharia principles are provisions, containing guidance and prohibitions, which bind the entire life of Muslims in the practice of worship and social interaction (muamalah) [1]. The principles are taught at the primary source of Islamic law, consisting of the Quran and Sunnah (teachings and deeds) of the Prophet peace be upon him (PBUH) [1], and complemented by the thought of scholars (ijtihad), in the form of consensus (ijma) and analogy (qiyas), as secondary sources [2].

The tenets prohibit the practice of usury, uncertainty (gharar), speculative actions (maysir) and conducting transactions related to illicit goods. Those prohibitions aim to promote justice, productivity and distribution of welfare among the people [3]. Therefore, Islamic financial institutions (IFIs) stand apart from their conventional peers in the use of interest-based products, which are considered as exploitative [4]. As an alternate of usury products, IFIs use profit and loss sharing method, which encourages equality in risk sharing between all parties involved. Therefore, Islamic banks were established to facilitate financial transactions which comply to sharia principles [5]. 
Since its first establishment, Islamic banks have grown rapidly and continue to be adopted worldwide, including countries which most population is non-Muslim [6]. In addition to religiosity, as the main reason of Islamic banking adoption [7 - 8], customers also consider other factors, such as: service quality [9 - 10], efficiency and easiness [11 - 12], transaction costs and bank reputation [13].

The adoption of Islamic banking in Indonesia begun almost thirty years ago, with the establishment of Bank Muamalat Indonesia. Regardless of its remarkable growth, the Indonesia Financial Services Authority (OJK) reported that Islamic banking market share was less than six percent in 2018 [14], which is quite small compared to the total Muslim population in the country [15]. Eventhough there are conversions of several regional government-owned banks to be Islamic banks in Aceh and West Nusa Tenggara, the growth of market share remains slow.

While Indonesia Islamic banks struggle to increase the market share, they face new challenge by financial technology companies (fintech). Digitalization has transformed financial industry as a response to the change of customer behavior [16]. Instead of cash-based transactions, people now prefer to use mobile banking services [17]. Thus, banks are expected to develop complete electronic banking solution [12], [18], in order to retain their existing customers as well as acquiring the new market [19].

As of October 2018, OJK [20] has registered 73 fintech companies, including two Islamic fintech. However, the number is still biased, considering that more fintech have not been registered yet. Deputy Commissioner of OJK, as cited by Asia News Monitor [21], underlines that the emergence of fintech may boost Islamic finance market share due to fintech has more flexibility to attract underserved customers. Instead of merely encourage the financial inclusion, fintech are feared to disrupt existing traditional industry players, including Islamic banks. PwC [22] at 2017 reported that fintech are predicted to take over the financing sector up to $84 \%$ and the fund transfer businesses up to $68 \%$.

The emergence of fintech has urged many studies to investigate the disruption effects. Nonetheless, only few of the studies associate the effects of digitalization with the problem of Indonesia Islamic banking market share stagnation. By analyzing primary data collected from respondents, this study attempts to identify the factor that most considered by customers in making decision to select financial service provider. The framework is constructed using the SERVQUAL model, the Unified Theory of Acceptance and Use of Technology 2 (UTAUT2) model and religiosity dimension. The research is expected to help Islamic banks managements and fintech industry players to capture public perception and to determine appropriate strategy needed in the digital era. The remaining section of this paper will be organized as following: (1) next section will describe the methodology of this research; (2) the results of model processing will be explained at the third section; whereas (3) last section reveals the conclusion of this research that will benefit as a discussion for further researches.

\section{Methodology}

This research is conducted by distributing online questionnaire, which is divided into two sections. The first part is arranged using five-point Likert scale, ranging from "strongly disagree" to "strongly agree", and contains questions about customers perceived of service quality, technology acceptance, religiosity and their decision to adopt Islamic banks and fintech. The second part is proposed to figure out respondent's profile. We do not strictly limit the respondents to customers of Islamic banks and fintech, in order to gather broader understanding 
of customers' perception, which is needed for market acquisition strategy. Convenience sampling technique is chosen, because it is more suitable for exploratory purpose [23].

This research model is a combination of SERVQUAL model, UTAUT2 model and religiosity factors. We also consider age as a dimension affecting customer intention in using services provided by Islamic bank or fintech, as be done in UTAUT model. We employ different approach regarding religiosity in the construction of Islamic banks selection and fintech selection. The religiosity dimensions become moderating factor towards technology acceptance in fintech selection, whereas the dimensions will directly affect the selection of Islamic banks. Based on aforementioned explanation, we propose following hypotheses:

\section{A. Service Quality Dimensions}

Today, the company's reputation is more vulnerable as a result of the escalation in customers activities on social media. Poor service quality will elicit sharp criticism that will easily become an issue in communities. Hence, management is required to pay more attention and establish appropriate strategies to maintain service quality [9]. Bank management should realize that the cost of acquiring new customers is very expensive, as well as the cost of losing loyal customers who are not satisfied with the services [24].

The most adopted model of service quality is SERVQUAL, which was introduced by Parasuraman et al. [25]. Instead of using original SERVQUAL, many researches apply several modifications, as shown in Table 1, because SERVQUAL is occasionally not suitable in certain contexts [26]. For instance, SERVQUAL does not consider sharia compliant which known as an important issue among Muslim communities. Therefore, many studies use CARTER model which modifies the original SERVQUAL with the addition of religiosity dimension [27].

Table 1. The use of SERVQUAL model

\begin{tabular}{|c|c|c|}
\hline No & Author & Dimensions \\
\hline 1 & $\begin{array}{l}\text { Rehman and Masood } \\
\text { (2012) [7] }\end{array}$ & $\begin{array}{ll}\text { 1. } & \text { Secure feeling } \\
\text { 2. } & \text { Banking services offered } \\
\text { 3. } & \text { Efficiency (prompt of service) } \\
\text { 4. } & \text { Religious factor } \\
\text { 5. } & \text { Quality related issues } \\
\text { 6. } & \text { Responsiveness } \\
\text { 7. } & \text { Attractiveness } \\
\text { 8. } & \text { Convenience } \\
\end{array}$ \\
\hline 2 & $\begin{array}{l}\text { Ahmed, Vveinhardt, } \\
\text { Štreimikiené, Ashraf, } \\
\text { and Channar (2017) } \\
{[28]}\end{array}$ & $\begin{array}{ll}\text { 1. } & \text { Empathy } \\
\text { 2. } & \text { Reliability } \\
\text { 3. } & \text { Competence } \\
\text { 4. } & \text { Online banking } \\
\text { 5. } & \text { Perceived value } \\
\text { 6. } & \text { Trust } \\
\text { 7. } & \text { Technology } \\
\end{array}$ \\
\hline 3 & Lujja et al. (2018) [4] & $\begin{array}{ll}\text { 1. } & \text { Third party influence } \\
\text { 2. Status (reputation, wide range of service) } \\
\text { 3. Convenience } \\
\text { 4. Profitability } \\
\text { 5. Hospitality } \\
\text { 6. } \\
\end{array}$ \\
\hline
\end{tabular}


Using the dimensions of service quality as suggested by Parasuraman [25], we construct following hypotheses:

H1A : Physical appearance of services (TAN) will significantly influence respondents' decision in using Islamic bank (IB) services.

H1B : Physical appearance of services will significantly influence respondents' decision in using fintech (FN) services.

H2A : Reliability (REL) will significantly influence respondents' decision in using Islamic bank services.

H2B : Reliability will have a positive and significant influence on respondents' decision in using fintech services.

H3A : Responsiveness in performing services (RES) will significantly influence respondents' decision in using Islamic bank services.

H3B : Responsiveness in performing services will significantly influence respondents' decision in using fintech services.

H4A : Assurance in conducting transactions (ASS) will significantly influence respondents' decision in using Islamic bank services.

H4B : Assurance in conducting transactions will significantly influence respondents' decision in using fintech services.

H5A : Empathy shown by the financial service provider (EMP) will significantly influence respondents' decision in using Islamic bank services.

H5B : Empathy shown by the financial service provider will significantly influence respondents' decision in using fintech services.

\section{B. Technology Acceptance Dimensions}

Advanced information system (IS) innovations, such as blockchain, artificial intelligence, and big data, are believed to leave the old financial industry players, who fail to adopt the technology [29]. However, customers embrace technology-based financial product not limited to the technological innovations created. Instead Dawson et al. [30] reveal that the disruption is fostered by the weakness of incumbent to address unseen menace, such as latent potential of micro-fund and unmet demand for fast and ease financing. Relishing the ubiquitous utilization of smartphone, fintech offers financial services to their customers [31] and exploits the crevices of disruption in financial industry. Other advantage is that fintech is neither required to build their own outlets nor limited by restrictive regulations [32]. Hence, fintech can reduce cost significantly and becomes more agile than traditional industry players.

Despite many concerns related to technology abuse, transformation of financial industry through digitalization is required as an effort to address the change of customers' behavior [16]. Therefore, researchers already study the adoption of technology over time. Among several technology adoption models, the UTAUT2 model introduced by Venkatesh et al. is the latest model [33]. Moreover, the model has been confirmed by Rondan-cataluña et al. to be better than other well-known model, such as Technology Acceptance Model (TAM) [34]. UTAUT2 consists of dimensions: (1) performance expectancy (PE); (2) effort expectancy (EE); (3) social influence (SI); (4) facilitating conditions (FC); (5) hedonic motivation (HM); (6) price value (PV); and (7) habit (HT)[33]. The use of UTAUT model can be found in many researches, as listed in Table 2. 
Table 2. The use of UTAUT2 model

\begin{tabular}{|c|c|}
\hline Author & Dimensions \\
\hline $\begin{array}{l}\text { 1. Afshan and Sharif } \\
\text { (2015) [35] }\end{array}$ & $\begin{array}{ll}\text { - } & \text { Performance expectancy } \\
\text { - } & \text { Effort expectancy } \\
\text { - } & \text { Social influence } \\
\text { - } & \text { Facilitating conditions } \\
\text { - } & \text { Task Technology Fit } \\
\text { - } & \text { Initial trust } \\
\end{array}$ \\
\hline $\begin{array}{ll}2 . & \text { Boonsiritomachai and } \\
& \text { Pitchayadejanant (2017) } \\
& {[19]}\end{array}$ & $\begin{array}{ll}\text { - } & \text { Performance expectancy } \\
\text { - } & \text { Effort expectancy } \\
\text { - } & \text { Social influence } \\
\text { - } & \text { Facilitating conditions } \\
\text { - } & \text { Security } \\
\text { - } & \text { Self-efficacy } \\
\end{array}$ \\
\hline $\begin{array}{l}\text { 3. Oliveira, Thomas, } \\
\text { Baptista and Campos } \\
\text { (2016) [17] }\end{array}$ & $\begin{array}{l}\text { - } \text { Compatibility } \\
\text { - Innovativeness } \\
\text { - Performance expectancy } \\
\text { - Effort expectancy } \\
\text { - Social influence } \\
\text { - Facilitating conditions } \\
\text { - Hedonic motivation } \\
\text { - Price value } \\
\text { - Perceived security }\end{array}$ \\
\hline
\end{tabular}

Based on the aforementioned UTAUT2 model, we suggested following hypotheses:

H6A : Performance improvement by using technology (PE) will significantly influence respondents' decision in using Islamic bank services.

H6B : Performance improvement by using technology will significantly influence respondents' decision in using fintech services.

H7A : Convenience effort in using the services (EE) will significantly influence respondents' decision in using Islamic bank services.

H7B : Convenience effort in using the services will significantly influence respondents' decision in using fintech services.

H8A : Social influence (SI) will significantly influence respondents' decision in using Islamic bank services.

H8B : Social influence will significantly influence respondents' decision in using fintech services.

H9A : The existence of facility to support the services (FC) will significantly influence respondents' decision in using Islamic bank services.

H9B : The existence of facility to support the services will significantly influence respondents' decision in using fintech services.

H10A : Hedonic motivation (HM) will significantly influence respondents' decision in using Islamic bank services.

H10B : Hedonic motivation will significantly influence respondents' decision in using fintech services. 
H11A : Respondents' habit in using technology-based financial products (HT) will significantly influence respondents' decision in using Islamic bank services.

H11B : Respondents' habit in using technology-based financial products will significantly influence respondents' decision in using fintech services.

H12A : Consideration of price value (PV) will significantly influence respondents' decision in using Islamic bank services.

H12B : Consideration in price value will significantly influence respondents' decision in using fintech services.

\section{Religiosity Dimensions}

Religiosity of a person, which is usually seen from his pious and spirit in religion [36], must be realized by practicing religious teachings as well [37]. Salleh [36] mentions that religiosity can be measured by: (1) the degree of belief, (2) knowledge of the teachings; (3) worship and deeds in daily lives; and (4) spiritual experience. The degree of religiosity may be different among Muslims. The most righteous fulfill their obligation obediently, as well as conform to all sharia principles [38]. In term of the sharia compliance in financial transaction, Usman et al. [37] found that not all Muslim obey the tenets, and only those who perceived bank interest as usury strictly choose Islamic banks while conducting their transactions. However, most studies confirm that religiosity become one of the considerations of customers when they choose Islamic bank [2], [7], [8], [39]. Hence, we proposed following hypotheses:

H13A : One's belief (BL) will significantly influence respondents' decision in using Islamic bank services.

H13B : Religiosity knowledge (RK) will significantly influence respondents' decision in using Islamic bank services.

H13C : Religiosity practices (RP) will significantly influence respondents' decision in using Islamic bank services.

H14A : One's belief will significantly moderate the relationship between social influence and respondents' decision in using fintech services.

H14B : Religiosity knowledge will significantly moderate the relationship between social influence and respondents' decision in using fintech services.

H14C : Religiosity practices will significantly moderate the relationship between social influence and respondents' decision in using fintech services.

H15A : One's belief will significantly moderate the relationship between the consideration of price value and respondents' decision in using fintech services.

H15B : Religiosity knowledge will significantly moderate the relationship between the consideration of price value and respondents' decision in using fintech services.

H15C : Religiosity practices will significantly moderate the relationship between the consideration of price value and respondents' decision in using fintech services.

\section{Age Dimensions}

The age of respondent is believed to influence their proficiency in using technology-based products, as has been indicated in many researches [27], [40]. Therefore, we suggested following hypotheses: 
H16A : Age (AG) will significantly influence respondents' decision in using Islamic bank services.

H16B : Age will significantly influence respondents' decision in using fintech services.

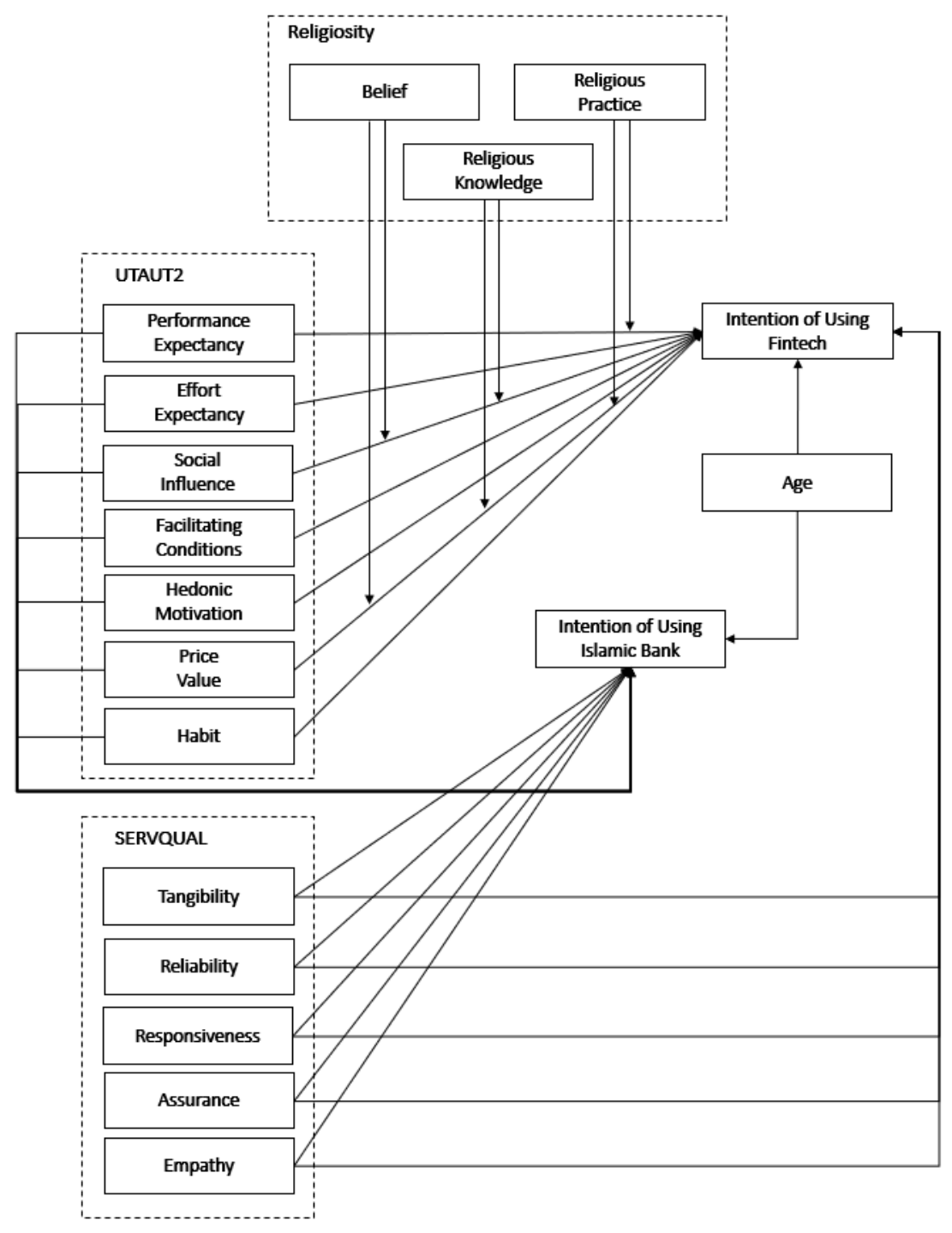

Figure 1. Conceptual framework

The model shown in Figure 1 is hereafter evaluated using Structural Equation Modeling (SEM). We choose Partial Least Square (PLS) method for hypotheses analysis, and the data is thereafter calculated using SmartPLS 3 software [41]. The decision to use PLS, which is also known as variance-based technique, lies in the following considerations: 
1. Common objective of using PLS is to optimize variance explained by endogenous constructs [42], which means that PLS is more appropriate to examine new model which has not been widely studied in previous researches [17], [43].

2. PLS is better than covariance-based SEM (CB-SEM) in term of its ability to analyze constructs with less than three indicators, and moreover PLS is capable to analyze model with a large number of indicators as well [42].

\section{Results}

\subsection{Sample Size and Respondents' ${ }^{6}$ Profile}

After carefully analyze the response, 404 response of 411 submitted questionnaires are deemed feasible for further analysis. The sample size is reasonably sufficient for analysis using PLS-SEM. Hair et al. [44] suggested that minimum sample size for PLS is ten times the maximum number of formative indicators to measure single construct. Using Kaiser-MeyerOlkin (KMO) test, Table 3 exhibits the KMO value is 0.828 , which is greater than benchmark value of 0.50 [28]. Thus, sample taken already satisfied sampling adequacy criteria. The probability of Bartlett's test, as indicated by p-value, achieves statistical significance $(0.000)$. Hence, the existing sample has met criteria of factor analysis.

Table 3. KMO and Bartlett's test

\begin{tabular}{|c|c|c|}
\hline & \multirow{3}{*}{$\begin{array}{r}\text { Result } \\
0.828 \\
6984.065\end{array}$} \\
\hline & & \\
\hline & & \\
\hline & $\begin{array}{ll} & \text { Evaluation } \\
\text { Kaiser-Meyer-Olkin Measure of Sampling Adequacy } \\
\text { Bartlett's Test of } & \text { Approx. Chi Square } \\
\text { Sphericity } & \text { Df }\end{array}$ & \multirow{2}{*}{$\begin{array}{r}861 \\
0.000\end{array}$} \\
\hline & Sig & \\
\hline
\end{tabular}

The number of male respondents $(53.96 \%)$ is higher than female $(46.04 \%)$. In terms of age, most of respondents (56.44\%) are millennials, whose age are between 18 - 35 years old. Meanwhile, only few of respondents are the oldest generation (9.16\%). Respondents are mainly well educated, as most of them (95.8\%) are diploma graduates or higher degree. More than half of respondents $(66.83 \%)$ are employees in government and non-government sectors. Majority of respondents $(75.99 \%)$ are the upper middle-class population, whose monthly household expenditure is equal to or higher than IDR 2 million.

Table 4. Respondents profile

\begin{tabular}{lrr}
\hline \multicolumn{1}{c}{ Group of Respondent } & Frequency & Percentage \\
\hline Gender & & \\
\hline Male & 218 & 53.96 \\
Female & 186 & 46.04 \\
\hline Education & & \\
\hline Elementary - High School & 17 & 4.21 \\
Diploma / Bachelor & 243 & 60.15 \\
Higher degree & 144 & 35.64 \\
\hline
\end{tabular}




\begin{tabular}{lrr}
\hline Age & & \\
\hline $18-25$ & 57 & 14.11 \\
$26-35$ & 171 & 42.33 \\
$36-45$ & 112 & 27.72 \\
$46-55$ & 27 & 6.68 \\
$>55$ & 37 & 9.16 \\
\hline
\end{tabular}

Table 4. Respondents profile (continuance)

\begin{tabular}{lrr}
\hline \multicolumn{1}{c}{ Group of Respondent } & Frequency & Percentage \\
\hline Job & & \\
Non-formal Job and Others & 41 & 10.15 \\
Student & 56 & 13.86 \\
Government Employees & 80 & 19.80 \\
Non-Government Employees & 190 & 47.03 \\
Entrepreneur & 37 & 9.16 \\
\hline Monthly household expenditure (IDR) & & \\
$<1$ million & 20 & 4.95 \\
1 million $-<1.5$ million & 37 & 9.16 \\
1.5 million $-<2$ million & 40 & 9.90 \\
2 million $-<3$ million & 44 & 10.89 \\
3 million $-<5$ million & 98 & 24.26 \\
5 million $-<7.5$ million & 67 & 16.58 \\
$>7.5$ million & 98 & 24.26 \\
\hline
\end{tabular}

\subsection{Construct Validity and Reliability}

According to Hair et al. [44], composite reliability (CR) of each construct should be higher than 0.70 and the convergent validity, measured by the average variance extracted (AVE), should be higher than 0.50 . Suppose the requirement of construct validity and reliability could not be achieved, particular of those indicators should be omitted only if it could increase the value of CR and AVE as suggested [44].

Table 5. Construct validity and reliability

\begin{tabular}{|c|c|c|c|c|c|}
\hline Dimension & Construct & Indicator & Loading & $\begin{array}{l}\text { Composite } \\
\text { Reliability }\end{array}$ & AVE \\
\hline \multirow{12}{*}{$\begin{array}{l}\text { Service } \\
\text { Quality }\end{array}$} & \multirow{2}{*}{ TAN } & TAN1 & 0.778 & \multirow{2}{*}{0.816} & \multirow{2}{*}{0.690} \\
\hline & & TAN2 & 0.880 & & \\
\hline & \multirow{2}{*}{ REL } & REL1 & 0.681 & \multirow{2}{*}{0.745} & \multirow{2}{*}{0.596} \\
\hline & & REL2 & 0.853 & & \\
\hline & \multirow{3}{*}{ RES } & RES1 & 0.743 & \multirow{3}{*}{0.789} & \multirow{3}{*}{0.556} \\
\hline & & RES2 & 0.805 & & \\
\hline & & RES3 & 0.684 & & \\
\hline & \multirow{3}{*}{ ASS } & ASS1 & 0.732 & \multirow{3}{*}{0.843} & \multirow{3}{*}{0.642} \\
\hline & & ASS2 & 0.792 & & \\
\hline & & ASS3 & 0.874 & & \\
\hline & \multirow{2}{*}{ EMP } & EMP1 & 0.697 & \multirow{2}{*}{0.785} & \multirow{2}{*}{0.650} \\
\hline & & EMP2 & 0.902 & & \\
\hline \multirow{3}{*}{$\begin{array}{l}\text { Technology } \\
\text { Acceptance }\end{array}$} & \multirow{2}{*}{ PE } & PE1 & 0.945 & \multirow{2}{*}{0.907} & \multirow{2}{*}{0.830} \\
\hline & & PE2 & 0.876 & & \\
\hline & $\mathrm{EE}$ & EE1 & 0.836 & 0.880 & 0.786 \\
\hline
\end{tabular}




\begin{tabular}{cccccc}
\cline { 2 - 3 } & EE2 & 0.934 & & \\
\hline \multirow{3}{*}{ SI } & SI1 & 0.817 & & \\
\cline { 2 - 3 } & SI2 & 0.838 & 0.850 & 0.655 \\
\cline { 2 - 3 } & SI3 & 0.771 & 0.877 & 0.704 \\
\cline { 2 - 3 } FC & FC1 & 0.795 & & \\
\cline { 2 - 3 } & FC2 & 0.840 & & \\
\cline { 2 - 3 } & FC3 & 0.879 & & &
\end{tabular}

Table 5. Construct validity and reliability (continuance)

\begin{tabular}{|c|c|c|c|c|c|}
\hline Dimension & Construct & Indicator & Loading & $\begin{array}{l}\text { Composite } \\
\text { Reliability } \\
\end{array}$ & AVE \\
\hline \multirow{7}{*}{$\begin{array}{l}\text { Technology } \\
\text { Acceptance }\end{array}$} & \multirow{2}{*}{ HM } & HM1 & 0.857 & \multirow{2}{*}{0.861} & \multirow{2}{*}{0.757} \\
\hline & & HM2 & 0.883 & & \\
\hline & \multirow{3}{*}{ PV } & PV1 & 0.691 & \multirow{3}{*}{0.815} & \multirow{3}{*}{0.597} \\
\hline & & PV2 & 0.863 & & \\
\hline & & PV3 & 0.755 & & \\
\hline & \multirow{2}{*}{ HT } & HT1 & 0.734 & \multirow{2}{*}{0.773} & \multirow{2}{*}{0.631} \\
\hline & & HT2 & 0.851 & & \\
\hline \multirow{7}{*}{ Religiosity } & \multirow{2}{*}{$\mathrm{BL}$} & PE1 & 0.912 & \multirow{2}{*}{0.936} & \multirow{2}{*}{0.879} \\
\hline & & PE2 & 0.962 & & \\
\hline & \multirow{2}{*}{ RK } & RK1 & 0.878 & \multirow{2}{*}{0.868} & \multirow{2}{*}{0.767} \\
\hline & & RK2 & 0.874 & & \\
\hline & \multirow{3}{*}{$\mathrm{RP}$} & RP1 & 0.836 & \multirow{3}{*}{0.872} & \multirow{3}{*}{0.695} \\
\hline & & RP2 & 0.876 & & \\
\hline & & RP3 & 0.788 & & \\
\hline \multirow{6}{*}{ Intention } & \multirow{3}{*}{ IB } & IB1 & 0.799 & \multirow{3}{*}{0.840} & \multirow{3}{*}{0.637} \\
\hline & & IB2 & 0.767 & & \\
\hline & & IB3 & 0.828 & & \\
\hline & \multirow{3}{*}{ FN } & FN1 & 0.815 & \multirow{3}{*}{0.814} & \multirow{3}{*}{0.598} \\
\hline & & FN2 & 0.626 & & \\
\hline & & FN3 & 0.859 & & \\
\hline
\end{tabular}

The results, as represented in Table 5, indicate that the data already meet the minimum requirements for validity and reliability, because the composite reliabilities has exceeded the threshold value at $\alpha>0.70$, and the AVEs are greater than 0.50. Although some indicators exhibit lower loading factor, the value is still greater than 0.400 . Hence, those indicators will still be used in the subsequent analysis, as suggested by Hair et al. [44].

The evaluation of descriptive statistics reveals that most respondents prioritize the existence of self-service financial infrastructure rather than the availability of financial service providers' office branches. Most of respondents $(99,26 \%)$ also perceive that assurance in conducting transactions, such as supervision by financial service authority, is important.

Almost all respondents suggest the utilization of self-conducted financial services to improve productivity, and most of them $(97.03 \%)$ do not find any difficulties in using those services. Customers are more likely to be influenced by family or peers $(71.04 \%)$, in using technology-based financial services, rather than following trends or influenced by advertising $(60.15 \%)$. Most respondents also argue that using technology-based financial services will be more efficient than conducting transactions at financial service providers' offices. 
Despite almost all respondents believe in Allah and the teachings in the Quran and Sunnah, many of them (3.71\%) do not recognize the obligation to conduct transactions in accordance with sharia principles, and more respondents $(6.68 \%)$ cannot distinguish the difference in Islamic financial practices from conventional ones. Therefore, there are pretty much respondents who do not strictly use Islamic financial products $(37.13 \%)$, and furthermore they do not make extra efforts to abandon the practices of usury (14.36\%).

\subsection{Discriminant Validity and Collinearity}

High correlations between indicators, referred as collinearity, is crucial in structural model [44]. Therefore, Hair et al. [44] recommend the assessment of variance inflation factor (VIF) to determine the presence of collinearity. Furthermore, Hair et al. [44] suggested VIF value should be lower than five to avoid collinearity problems. As be seen in Table 6, the data is clean of collinearity problems.

\begin{tabular}{|c|c|c|}
\hline & IB & FN \\
\hline TAN & 1.352 & 1.427 \\
\hline REL & 1.846 & 1.860 \\
\hline RES & 1.663 & 1.688 \\
\hline ASS & 1.441 & 1.474 \\
\hline EMP & 1.596 & 1.675 \\
\hline PE & 2.481 & 2.505 \\
\hline $\mathrm{EE}$ & 2.396 & 2.411 \\
\hline SI & 1.530 & 1.644 \\
\hline $\mathrm{FC}$ & 2.105 & 2.154 \\
\hline HM & 1.633 & 1.673 \\
\hline HT & 1.696 & 1.702 \\
\hline PV & 1.415 & 1.573 \\
\hline BL & 1.254 & 1.345 \\
\hline RK & 2.209 & 2.356 \\
\hline $\mathrm{RP}$ & 2.255 & 2.361 \\
\hline AG & 1.124 & 1.163 \\
\hline \multicolumn{3}{|c|}{ *) Moderating factor } \\
\hline$P V \times B L \times F N$ & & 1.365 \\
\hline PV x RK $x$ FN & & 2.501 \\
\hline PV x RP x FN & & 2.187 \\
\hline SI $x$ BL $x$ FN & & 1.433 \\
\hline SI x RK x FN & & 2.485 \\
\hline SI $x$ RP $x$ FN & & 2.356 \\
\hline
\end{tabular}

\subsection{Structural Model Evaluation}

Bootstrap method using 5,000 sub-samples at 5\% significance level is used to conduct hypotheses analysis as suggested by [44]. The coefficient of determination $\left(R^{2}\right)$ for the construct of behavior intention in using Islamic banks is 0.528 . Meanwhile, $R^{2}$ reported for the behavior intention in using fintech is 0.156 . This implies that the model fairly explains the customers behavior in choosing Islamic banks, better than customers behavior in using fintech services. Although there is no tight standard of $R^{2}$, as a rule of thumb in marketing fields, Hair et al. [44] explain that values of $0.75,0.50$, or 0.25 are respectively described as substantial, moderate, or 
weak. The reported value of standardized root mean square residual (SRMR) is 0.073 , thus already satisfies the minimum fit criteria of 0.08 as recommended by $\mathrm{Hu}$ and Bentler [45].

The findings, as seen in Table 7, indicate that the major factor which drives customer behavior to embrace Islamic banks is the practice of religiosity, whereas one's belief surprisingly does not affect the behavior. The other factors, which significantly influence customers' decision in using Islamic bank services, are religiosity knowledge and expectancy of performance improvement while using technology-based services. Other dimensions do not seem to support the hypotheses of choosing Islamic banks. These findings explain the stagnation of Indonesian Islamic banking market share, despite the number of Muslim population in the country is a boon to the Islamic bank industry. Moreover, the customers of Islamic banks perceive that the development of technology-based products is important, hence the banks should focus their effort on providing self-service products, aside from raising customer awareness regarding Islamic financial system continuously.

Table 7. Hypotheses testing

\begin{tabular}{|c|c|c|c|c|c|}
\hline \multirow{2}{*}{$\begin{array}{c}\text { Hypothesis } \\
\text { H1A }\end{array}$} & \multicolumn{2}{|c|}{ Relationship } & \multirow{2}{*}{$\begin{array}{c}\begin{array}{c}\text { Original } \\
\text { Sample (O) }\end{array} \\
-0.003\end{array}$} & \multirow{2}{*}{$\begin{array}{c}\text { T-Statistics } \\
0.061\end{array}$} & \multirow{2}{*}{$\begin{array}{c}\text { Result } \\
\text { Not significant }\end{array}$} \\
\hline & TAN & $\rightarrow$ IB & & & \\
\hline H1B & TAN & $\rightarrow \mathrm{FN}$ & -0.060 & 0.802 & Not significant \\
\hline $\mathrm{H} 2 \mathrm{~A}$ & REL & $\rightarrow$ IB & -0.032 & 0.647 & Not significant \\
\hline $\mathrm{H} 2 \mathrm{~B}$ & REL & $\rightarrow \mathrm{FN}$ & -0.013 & 0.194 & Not significant \\
\hline H3A & RES & $\rightarrow$ IB & 0.047 & 0.964 & Not significant \\
\hline H3B & RES & $\rightarrow \mathrm{FN}$ & 0.005 & 0.073 & Not significant \\
\hline $\mathrm{H} 4 \mathrm{~A}$ & ASS & $\rightarrow \mathrm{IB}$ & -0.008 & 0.184 & Not significant \\
\hline $\mathrm{H} 4 \mathrm{~B}$ & ASS & $\rightarrow \mathrm{FN}$ & -0.124 & 2.004 & Significant \\
\hline $\mathrm{H} 5 \mathrm{~A}$ & EMP & $\rightarrow$ IB & 0.067 & 1.355 & Not significant \\
\hline H5B & EMP & $\rightarrow \mathrm{FN}$ & 0.048 & 0.732 & Not significant \\
\hline H6A & PE & $\rightarrow$ IB & 0.142 & 2.428 & Significant \\
\hline H6B & $\mathrm{PE}$ & $\rightarrow \mathrm{FN}$ & 0.012 & 0.156 & Not significant \\
\hline $\mathrm{H} 7 \mathrm{~A}$ & $\mathrm{EE}$ & $\rightarrow$ IB & -0.067 & 1.284 & Not significant \\
\hline $\mathrm{H} 7 \mathrm{~B}$ & $\mathrm{EE}$ & $\rightarrow \mathrm{FN}$ & 0.026 & 0.277 & Not significant \\
\hline $\mathrm{H} 8 \mathrm{~A}$ & SI & $\rightarrow$ IB & -0.050 & 1.108 & Not significant \\
\hline H8B & SI & $\rightarrow \mathrm{FN}$ & 0.139 & 2.034 & Significant \\
\hline H9A & $\mathrm{FC}$ & $\rightarrow \mathrm{IB}$ & 0.006 & 0.123 & Not significant \\
\hline H9B & $\mathrm{FC}$ & $\rightarrow \mathrm{FN}$ & -0.001 & 0.010 & Not significant \\
\hline $\mathrm{H} 10 \mathrm{~A}$ & $\mathrm{HM}$ & $\rightarrow$ IB & 0.068 & 1.477 & Not significant \\
\hline $\mathrm{H} 10 \mathrm{~B}$ & HM & $\rightarrow \mathrm{FN}$ & -0.011 & 0.158 & Not significant \\
\hline $\mathrm{H} 11 \mathrm{~A}$ & HT & $\rightarrow$ IB & 0.037 & 0.720 & Not significant \\
\hline H11B & HT & $\rightarrow \mathrm{FN}$ & 0.060 & 0.912 & Not significant \\
\hline $\mathrm{H} 12 \mathrm{~A}$ & PV & $\rightarrow$ IB & 0.020 & 0.435 & Not significant \\
\hline $\mathrm{H} 12 \mathrm{~B}$ & PV & $\rightarrow \mathrm{FN}$ & 0.226 & 3.342 & Significant \\
\hline $\mathrm{H} 13 \mathrm{~A}$ & $\mathrm{BL}$ & $\rightarrow$ IB & 0.006 & 0.132 & Not significant \\
\hline H13B & $\mathrm{RK}$ & $\rightarrow \mathrm{IB}$ & 0.291 & 4.545 & Significant \\
\hline $\mathrm{H} 13 \mathrm{C}$ & $\mathrm{RP}$ & $\rightarrow$ IB & 0.440 & 6.812 & Significant \\
\hline $\mathrm{H} 14 \mathrm{~A}$ & SI X E & L X FN & 0.004 & 0.079 & Not significant \\
\hline $\mathrm{H} 14 \mathrm{~B}$ & SI X R & $\mathrm{K} X \mathrm{FN}$ & -0.105 & 1.246 & Not significant \\
\hline $\mathrm{H} 14 \mathrm{C}$ & SI X F & $\mathrm{P} X \mathrm{FN}$ & 0.097 & 1.016 & Not significant \\
\hline $\mathrm{H} 15 \mathrm{~A}$ & PV X & $3 \mathrm{~L} X \mathrm{FN}$ & 0.025 & 0.409 & Not significant \\
\hline $\mathrm{H} 15 \mathrm{~B}$ & PV X I & $\mathrm{KK} X \mathrm{FN}$ & 0.020 & 0.233 & Not significant \\
\hline $\mathrm{H} 15 \mathrm{C}$ & PV X & $\mathrm{RP} X \mathrm{FN}$ & 0.026 & 0.287 & Not significant \\
\hline $\mathrm{H} 16 \mathrm{~A}$ & $\mathrm{AG}$ & $\rightarrow$ IB & -0.009 & 0.280 & Not significant \\
\hline $\mathrm{H} 16 \mathrm{~B}$ & $\mathrm{AG}$ & $\rightarrow \mathrm{FN}$ & -0.048 & 0.994 & Not significant \\
\hline
\end{tabular}


The customers intention in using fintech services mostly influenced by the consideration of price and value while using technology-based financial products. Customers are also influenced by their surrounding environments, such as peers, family, advertisements, and trends in using fintech services. Nevertheless, the results show that the lack of supervision to fintech companies and some negative reporting by media have negative influence on the assurance factor.

Although the findings are not significant, this research find that customers are no longer viewed that physical offices of financial service providers as an important factor that influence their decision. The results also imply that Islamic bank also encounter negative social influence, which may be caused by dispute among public of sharia compliance in Indonesia Islamic banking practices. Meanwhile, Islamic banks are perceived to have insufficient number of physical branch offices, although it is not significant affected customers' decision.

\section{Discussion}

The results conform prior research conducted by Usman et al. [37] that Islamic banking in Indonesia could not merely rely on the size of Muslim population. Banking practices, in accordance with sharia principles and the provisions of financial authorities, have not been able to convince the public in using Islamic banks. Moreover, Islamic banks office networks and their self-service infrastructure are deemed to be still inadequate to reach entire community, despite a large number of physical outlets may not be necessary in the future.

This research also emphasizes that, even though SERVQUAL model has been widely used by many researches, the behavioral changes of customers towards digitalization may need new measurement approach regarding service quality. In addition, the new model should embed religiosity and other cultural aspects as well to construct a complete framework, thus it could be used for generalization.

Therefore, in order to expand its market share, Islamic banks are suggested to arouse public awareness about the obligation of Muslims to comply with sharia provision in conducting financial transactions. The knowledge and discussion related to Islamic finance should be held more broadly, so that people can understand that Islamic teachings are not limited to worship. Islamic banks also required to advance their self-service products to fulfil customer expectation of performance improvement. 


\section{References}

[1] M. Todorof, "Shariah-compliant FinTech in the banking industry," ERA Forum, vol. 19, pp. 1-17, 2018.

[2] U. Riaz, M. Khan, and N. Khan, “An Islamic banking perspective on consumers' perception in Pakistan," Qual. Res. Financ. Mark., vol. 9, no. 4, pp. 337-358, 2017.

[3] I. Warde, Islamic Finance in the Global Economy. 2000.

[4] S. Lujja, M. O. Mohammed, and R. Hassan, "Islamic banking: an exploratory study of public perception in Uganda," J. Islam. Account. Bus. Res., vol. 9, no. 3, pp. 336-352, 2018.

[5] Ascarya and D. Yumanita, Bank Syariah: Gambaran Umum, vol. 14, no. 14. 2005.

[6] H. G. Rammal and L. D. Parker, "Islamic banking in Pakistan : A history of emergent accountability and regulation," Account. Hist., vol. 18, no. 1, pp. 5-29, 2012.

[7] A. A. Rehman and O. Masood, "Why do customers patronize Islamic banks? A case study of Pakistan," Qual. Res. Financ. Mark., vol. 4, pp. 130-141, 2012.

[8] A. Shome, F. Jabeen, and R. Rajaguru, "What drives consumer choice of Islamic banking services in the United Arab Emirates?," Int. J. Islam. Middle East. Financ. Manag., vol. 11, no. 1, pp. 79-95, 2018.

[9] N. Abdullrahim and J. Robson, "The importance of service quality in British Muslim's choice of an Islamic or non-Islamic bank account," J. Financ. Serv. Mark., vol. 22, no. 2, pp. 54-63, 2017.

[10] M. A. Janahi and M. M. S. Al Mubarak, "The impact of customer service quality on customer satisfaction in Islamic banking," J. Islam. Mark., vol. 8, no. 4, pp. 595-604, 2017.

[11] A. Echchabi and O. N. Olaniyi, "Malaysian consumers' preferences for Islamic banking attributes," Int. J. Soc. Econ., vol. 39, no. 11, pp. 859-874, 2012.

[12] M. Rashid and M. K. Hassan, "Customer Demographics Affecting Bank Selection Criteria, Preference, and Market Segmentation: Study on Domestic Islamic Banks in Bangladesh," Int. J. Bus. Manag., vol. 4, no. 6, pp. 131-146, 2009.

[13] A. Hamid and O. Masood, "Selection criteria for Islamic home financing: a case study of Pakistan," Qual. Res. Financ. Mark., vol. 3, no. 2, pp. 117-130, 2011.

[14] O. J. K. OJK, "Snapshot Perbankan Syariah Indonesia Posisi 30 Juni 2018," 2018. [Online]. Available: https://www.ojk.go.id/id/kanal/syariah/berita-dankegiatan/publikasi/Documents/Pages/Snapshot-Perbankan-Syariah-Indonesia-Juni-2018/Snapshot Juni 2018 (final).pdf. [Accessed: 20-May-2019].

[15] B. P. S. BPS, "Kewarganegaraan, Suku Bangsa, Agama, dan Bahasa Sehari-hari Penduduk Indonesia - Hasil Sensus Penduduk 2010,” 2011. [Online]. Available: http://demografi.bps.go.id/phpfiletree/bahan/kumpulan_tugas_mobilitas_pak_chotib/Kelompok_1/R eferensi/BPS_kewarganegaraan_sukubangsa_agama_bahasa_2010.pdf. [Accessed: 20-Jun-2018].

[16] K. Pousttchi and M. Dehnert, "Exploring the digitalization impact on consumer decision-making in retail banking," Electron. Mark., 2018.

[17] T. Oliveira, M. Thomas, G. Baptista, and F. Campos, "Mobile payment: Understanding the determinants of customer adoption and intention to recommend the technology," Comput. Human Behav., vol. 61, pp. 404-414, 2016.

[18] A. A. Shaikh and H. Karjaluoto, "Mobile banking adoption: A literature review," Telemat. Informatics, vol. 32, no. 1, pp. 129-142, 2015.

[19] W. Boonsiritomachai and K. Pitchayadejanant, "Determinants affecting mobile banking adoption by generation Y based on the Unified Theory of Acceptance and Use of Technology Model modified by the Technology Acceptance Model concept," Kasetsart J. Soc. Sci., pp. 1-10, 2017.

[20] O. J. K. OJK, "Penyelenggara Fintech Terdaftar di OJK per Oktober 2018," 2018. [Online]. Available: https://www.ojk.go.id/id/berita-dan-kegiatan/publikasi/Pages/Penyelenggara-FintechTerdaftar-di-OJK-per-Oktober-2018.aspx. [Accessed: 18-Jan-2019].

[21] AsiaNewsMonitor, "Indonesia: IMF - WB - Financial Services Authority promotes fintech for MSMEs, sharia finance," 2018.

[22] P. W. C. PWC, "Redrawing the lines: FinTech's growing influence on Financial Services," 2017.

[23] D. R. Cooper and P. S. Schindler, Business Research Methods, 12th ed. New York: McGraw- 
Hill, 2012.

[24] L. Saqib, M. A. Farooq, and A. M. Zafar, "Customer perception regarding Sharī'ah compliance of Islamic banking sector of Pakistan,” J. Islam. Account. Bus. Res., vol. 7, no. 4, pp. 282-303, 2016.

[25] A. Parasuraman, V. A. Zeithaml, and L. L. Berry, "A Conceptual Model of Service Quality and Its Implications for Future Research,” J. Mark., vol. 49, pp. 41-50, 1986.

[26] J. J. Cronin and S. A. Taylor, "Measuring Service Quality: A Reexamination And Extension," J. Mark., vol. 56, no. 3, pp. 55-68, 1992.

[27] A. Al-jazzazi and P. Sultan, "Demographic differences in Jordanian bank service quality perceptions,” Int. J. Bank Mark., vol. 35, no. 2, pp. 275-297, 2017.

[28] R. R. Ahmed, J. Vveinhardt, D. Štreimikienè, M. Ashraf, and Z. A. Channar, "Modified SERVQUAL Model And Effects of Customer Attitude And Technology on Customer Satisfaction in Banking Industry: Mediation, Moderation And Conditional Process Analysis," J. Bus. Econ. Manag., vol. 18 , no. 5, pp. 974-1004, 2017.

[29] P. Gomber, R. J. Kauffman, C. Parker, and B. W. Weber, "On the Fintech Revolution: Interpreting the Forces of Innovation, Disruption, and Transformation in Financial Services On the Fintech Revolution: Interpreting the Forces of Innovation, Disruption, and Transformation in Financial Services," J. Manag. Inf. Syst., vol. 35, no. 1, pp. 220-265, 2018.

[30] A. Dawson, M. Hirt, and J. Scanlan, "The economic essentials of digital strategy," McKinsey Q., no. 2, pp. 32-44, 2016.

[31] FintechWeekly, "Fintech Definition," 2018. [Online]. Available: https://www.fintechweekly.com/. [Accessed: 27-Jun-2018].

[32] Economist, "The Fintech Revolution," Economist, 2015. [Online]. Available: https://www.economist.com/leaders/2015/05/09/the-fintech-revolution. [Accessed: 27-Jun-2018].

[33] V. Venkatesh, J. Y. . Thong, and X. Xu, "Consumer Acceptance And Use of Information Technology: Extending The Unified Theory of Acceptance And Use of Technology," MIS Q., vol. 36, no. 1, pp. 157-178, 2012.

[34] F. J. Rondan-cataluña, J. Arenas-gaitán, and P. E. Ramírez-correa, “A comparison of the different versions of popular technology acceptance models A non-linear perspective," Kybernetes, vol. 44, no. 5, pp. 788-805, 2015.

[35] S. Afshan and A. Sharif, "Acceptance of mobile banking framework in Pakistan," Telemat. Informatics, vol. 33, no. 2, pp. 370-387, 2015.

[36] M. S. Salleh, "Religiosity in Development: A Theoretical Construct of an Islamic-Based Development," Int. J. Humanit. Soc. Sci., vol. 2, no. 14, pp. 266-274, 2012.

[37] H. Usman, P. Tjiptoherijanto, T. E. Balqiah, and I. G. N. Agung, "The role of religious norms , trust , importance of attributes and information sources in the relationship between religiosity and selection of the Islamic bank," J. Islam. Mark., vol. 8, no. 2, pp. 158-186, 2017.

[38] M. M. H. Abou-Youssef, W. Kortam, E. Abou-Aish, and N. El-Bassiouny, "Effects of religiosity on consumer attitudes toward Islamic banking in Egypt," Int. J. Bank Mark., vol. 33, no. 6, pp. 786$807,2015$.

[39] S. Wahyuni and N. Fitriani, "Brand religiosity aura and brand loyalty in Indonesia Islamic banking," J. Islam. Mark., vol. 8, no. 3, pp. 361-372, 2017.

[40] D. Chawla and H. Joshi, "The Moderating Effect of Demographic Variables on Mobile Banking Adoption : An Empirical Investigation," Glob. Bus. Rev., vol. 19, pp. 90S-113S, 2018.

[41] C. M. Ringle, S. Wende, and J.-M. Becker, "SmartPLS 3." SmartPLS GmbH, Boenningstedt, 2015.

[42] W. M. A. B. W. Afthanorhan, "A Comparison Of Partial Least Square Structural Equation Modeling (PLS-SEM) and Covariance Based Structural Equation Modeling (CB-SEM) for Confirmatory Factor Analysis," Int. J. Eng. Sci. Innov. Technol., vol. 2, no. 5, pp. 198-205, 2013.

[43] H. Amin, A.-R. Abdul-Rahman, and D. A. Razak, "Theory of Islamic consumer behaviour An empirical study of consumer behaviour of," J. Islam. Mark., vol. 5, no. 2, pp. 273-301, 2013.

[44] J. F. Hair, G. T. M. Hult, C. M. Ringle, and M. Sarstedt, A Primer on Partial Least Squares Structural Equation Modeling (PLS-SEM), 2nd ed. SAGE Publications, Inc, 2017.

[45] L. Hu and P. M. Bentler, "Fit Indices in Covariance Structure Modeling: Sensitivity to 
Underparameterized Model Misspecification," Psychol. Methods, vol. 3, no. 4, pp. 424-453, 1998. 